\title{
Manajemen Pemeliharaan Transformator Tegangan Menengah Berbasis Hasil Analisis Gas Terlarut
}

\author{
I G. N. Segara Putra*, W. G. Ariastina, I N. S. Kumara, W. Sukerayasa, I. A. D. Giriantari \\ Program Studi Magister Teknik Elektro, Universitas Udayana \\ Jalan P. B. Sudirman, Denpasar - 80000, Bali, Indonesia \\ *ignsegaraputra@ymail.com
}

\begin{abstract}
A simple approach for determination of maintenance priority of medium voltage transformers is discussed in this paper. The approach adopts simple weighting and scoring methods based on the DGA and oil breakdown voltage test results. The transformer peak load and operating temperature are also considered as decision parameters. The approach was applied in maintenance management of 29 transformers of a medium voltage distribution network supplying an international airport. Results of the study showed that the approach has been very useful for technician and engineer in determining the maintenance priority of the transformers.
\end{abstract}

Keywords-MV transformers; DGA test; maintenance schedule

Abstract - Sebuah pendekatan sederhana untuk menentukan prioritas pemeliharaan transformator dibahas dalam paper ini. Pendekatan yang digunakan mengadopsi metode pemberian bobot dan skor sederhana dengan melihat hasil analisis gas terlarut dan hasil uji tegangan tembus. Selain itu, pembebanan dan suhu operasi transformator juga digunakan sebagai parameter untuk penentuan prioritas perawatan. Metode ini telah diaplikasikan dalam manajemen perawatan 29 buah tranformator tegangan menengah yang menyuplai sebuah bandara internasional. Hasil penelitian menunjukkan bahwa pendekatan sederhana ini sangat berguna dalam membantu para teknisi untuk menentukan jadwal pemeliharaan transformator-transformator tersebut.

Kata kunci-transformator tegangan menengah; uji DGA; jadwal pemeliharaan.

\section{PENDAHULUAN}

Transformator dengan isolasi minyak telah diperkenalkan lebih dari satu abad yang lalu dan saat ini digunakan secara luas dalam industri ketenagalistrikan. Di dalam transformator berisolasi minyak, isolasi utama terdiri dari minyak transformator, kertas dan pressboard. Isolasi kertas, pressboard dan minyak transformator secara fisik terlihat rapuh, akan tetapi kombinasi dari ketiga material tersebut memiliki kekuatan isolasi listrik yang tinggi [1]. Hal ini mendorong digunakannya bahanbahan tersebut sebagai sistem isolasi transformator secara luas.

Seiring dengan beroperasinya transformator, bahan isolasi akan mengalami penuaan. Penuaan isolator tersebut disebabkan oleh gabungan dari berbagai faktor, misalnya: tekanan mekanis (akibat getaran atau ketegangan), tekanan termal (akibat arus beban atau arus hubung singkat) dan tekanan elektrik (akibat tegangan operasi atau tegangan lebih). Selain faktor-faktor tersebut, pengaruh lingkungan seperti kelembaban dan tingginya tingkat keasaman akan menyebabkan reaksi kimia yang dapat menyebabkan kerusakan isolasi lebih lanjut. Adanya penuaan isolasi tersebut dapat diamati berupa penurunan fungsi dari desain awal ataupun penurunan karakteristik isolasi yang diperlukan [2].

Bahan isolasi dikatakan mencapai batas umurnya ketika sifat listrik atau mekanis dari bahan tersebut tidak dapat dipertahankan lagi pada batas yang telah ditentukan. Dengan kata lain, bahan isolasi telah kehilangan kemampuan untuk menahan tekanan listrik atau mekanis. Sebagai akibat dari turunnya kemampuan tersebut adalah terjadi kegagalan isolasi. Kegagalan isolasi dalam transformator memiliki konsekwensi pemadaman sistem dan memerlukan biaya perawatan yang sangat tinggi.

Selain timbulnya resiko secara finansial, penurunan kemampuan isolasi juga dapat beresiko terhadap personil, utamanya yang berada di sekitar transformator. Konsekuensi yang mungkin lebih tinggi dapat terjadi dalam kasus transformator dioperasikan pada jaringan penyedia daya listrik untuk area penting, seperti rumah sakit dan bandar udara. Untuk itu diperlukan pemantauan kondisi isolasi transformator secara berkesinambungan, sehingga dapat mengurangi resiko yang mungkin terjadi, baik terhadap manusia maupun terhadap lingkungan sekitarnya.

Ada beberapa metode yang umum digunakan untuk memantau kondisi isolasi transformator. Saat ini, teknik pemantauan secara online lebih disukai karena sifatnya yang sangat fleksibel. Analisis kandungan gas terlarut (DGA) dan teknik partial discharge (PD) adalah metode yang paling umum digunakan dalam pemantauan secara online. DGA telah dikenal sejak puluhan tahun dan saat ini adalah uji isolasi yang paling banyak digunakan untuk pemantauan kondisi transformator.

Makalah ini menyajikan penentuan prioritas pemeliharaan transformator tegangan menengah berdasarkan hasil uji DGA. Pendekatan yang digunakan mengadopsi metode pemberian bobot dan skor sederhana berdasarkan hasil uji DGA dan hasil uji tegangan tembus. Pembebanan transformator dan suhu operasi juga digunakan sebagai parameter untuk klasifikasi dan 
pengambilan keputusan. Pendekatan sederhana tersebut diujikan dalam penentuan jadwal pemeliharaan 29 buah transformator tegangan menengah yang dioperasikan untuk menyuplai energi listrik sebuah bandara internasional. Gambar 1. Menunjukkan salah satu dari transformator yang diuji.

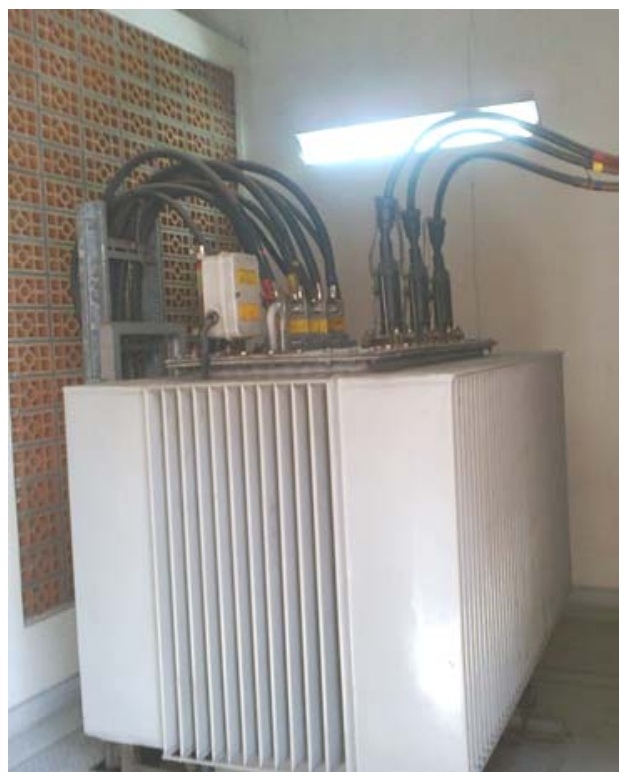

Gambar 1. Transformator tegangan menengah (20kV/400V, 2MVA)

\section{KLASIFIKASI PRIORITAS PEMELIHARAAN}

Berbagai penelitian yang berhubungan dengan pengambilan keputusan dalam manajemen aset telah banyak dilakukan. Hasil penelitian tersebut sangat berguna untuk membantu para pengambil keputusan dalam menentukan tindakan lebih lanjut terkait dengan aset-aset yang dimiliki oleh perusahaan penyedia energi listrik. Untuk pengambilan keputusan dalam manajemen aset, biasanya digunakan sejumlah parameter yang meliputi analisis teknis dan ekonomis. Dalam hal parameter teknis, nilai kandungan gas yang terlarut dalam minyak telah digunakan secara luas [3-7].

Penjadwalan perawatan trasformator yang dibahas dalam makalah ini menggunakan empat pendekatan interpretasi hasil uji DGA, yang meliputi metode TDCG, Key gas, Roger's ratio dan Duval's triangle. Tes tegangan tembus minyak transformator, pembebanan transformator dan suhu operasi transformator juga digunakan sebagai parameter pengambilan keputusan. Digunakannya parameter karakteristik transformator saat berbeban dan suhu operasi transformator didasarkan pada fakta bahwa laju degradasi isolasi transformator sangat bergantung pada kondisi operasi, khususnya suhu transformator. Dengan demikian, terdapat tujuh parameter klasifikasi yang digunakan untuk penjadwalan perawatan transformator.

Teknik penjadwalan perawatan transformator yang dibahas di sini terbagi dalam empat langkah yang meliputi pemberian bobot dan skor individu untuk setiap parameter yang akan digunakan dalam proses klasifikasi prioritas perawatan. Langkah berikutnya adalah perhitungan jumlah skor dan penentuan klasifikasi prioritas pemeliharaan berdasarkan jumlah skor untuk masing- masing transformator. Langkah terakhir adalah melakukan prosedur pemeliharahan transformator dengan mengikuti prioritas yang telah ditentukan.

\section{A. Langkah Pertama}

Proses klasifikasi prioritas pemeliharaan dimulai dengan pemberian bobot pada parameter-parameter yang digunakan dan memberikan skor individu untuk masingmasing kondisi hasil uji maupun pengukuran untuk tiap parameter. Komposisi bobot yang digunakan mengacu pada hasil penelitian pada [8] yang membandingkan tingkat akurasi berbagai metode interpretasi DGA. Hasil penelitian tersebut menempatkan metode Duval's triangle sebagai metode yang paling akurat disusul metode Roger's ratio dan key gas, serta TDCG dalam urutan terakhir. Pengalaman penulis dalam meneliti hasil uji DGA minyak transformator juga menunjukkan kemiripan hasil.

Tabel I menunjukkan pembobotan parameterparameter yang digunakan dalam penjadwalan perawatan transformator. Dengan mengacu pada tingkat akurasi seperti disebutkan sebelumnya, hasil interpretasi dengan menggunakan metode Duval's triangle diberikan bobot tertinggi yaitu 30, diikuti dengan metode Roger's ratio dan Key gas, masing-masing dengan bobot sebesar 20. Hasil interpretasi DGA dengan metode TDCG diberikan skor 10. Hasil uji tegangan tembus, pembebanan dan suhu operasi transformator masing-masing diberikan bobot 10 , 5 dan 5. Total bobot untuk seluruh parameter yang digunakan adalah 100 .

TABEL I. PEMBobotan PARAMETER KLASIFIKASI

\begin{tabular}{clc}
\hline No. & Parameter & Bobot \\
\hline 1 & TDCG & 10 \\
\hline 2 & Key gas & 20 \\
\hline 3 & Roger's ratio & 20 \\
\hline 4 & Duval's triangle & 30 \\
\hline 5 & Tegangan tembus & 10 \\
\hline 6 & Pembebanan & 5 \\
\hline 7 & Suhu operasi & 5 \\
\hline Total bobot & $\mathbf{1 0 0}$ \\
\hline
\end{tabular}

Skor individu yang diberikan untuk masing-masing parameter ditentukan berdasarkan hasil uji dan pengukuran. Skor maksimum dan selang nilai untuk setiap kondisi hasil uji dan pengukuran dapat ditentukan berdasarkan pengalaman penelitian sebelumnya maupun berdasarkan penilaian ahli. Contoh pemberian skor individu untuk hasil uji tegangan tembus minyak transformator ditunjukkan pada Tabel II.

TABEL II. PEMBERIAN SKOR INDIVIDU PADA HASIL TES TEGANGAN TEMBUS MINYAK TRANSFORMATOR

\begin{tabular}{ccc}
\hline No. & Hasil Tes & Skor individu \\
\hline 1 & $\mathrm{BDV} \geq 60 \mathrm{kV}$ & 25 \\
\hline 2 & $40 \leq \mathrm{BDV} \leq 60$ & 50 \\
\hline 3 & $20 \leq \mathrm{BDV} \leq 40$ & 75 \\
\hline 4 & $20 \leq \mathrm{BDV}$ & 100 \\
\hline
\end{tabular}


Semakin rendah hasil uji tegangan tembus, semakin tinggi skor yang diberikan. Dengan demikian transformator dengan kondisi minyak yang buruk akan memperoleh nilai tinggi untuk prioritas perawatan. Sebagai ilustrasi, jika hasil uji tegangan tembus minyak sebuah transformator berada di antara 40 dan $60 \mathrm{kV}$, maka diberikan skor individu sebesar 50, dengan bobot parameter 10 seperti tertera pada Tabel I.

\section{B. Langkah Kedua}

Langkah kedua adalah perhitungan jumlah skor yang merupakan penjumlahan dari skor individu yang dikalikan dengan bobot masing-masing parameter, kemudian dibagi dengan total bobot. Secara matematis, perhitungan jumlah skor dapat dinyatakan dalam persamaan [8]:

$$
T S=\left[\left(S_{1} \cdot W_{1}\right)+\left(S_{2} \cdot W_{2}\right)+\ldots+\left(S_{N} \cdot W_{N}\right)\right] /\left[W_{1}+W_{2}+\ldots+W_{N}\right]
$$

Dimana: TS adalah skor total, sedangkan $S_{n}$ adalah skor individu, dan $W_{n}$ adalah bobot dari masing-masing parameter. $N$ adalah jumlah parameter yang digunakan untuk klasifikasi.

\section{Langkah Ketiga}

Langkah ketiga adalah penentuan prioritas perawatan dengan melihat jumlah skor yang diperoleh. Skor total dapat dibagi menjadi beberapa selang, yang menunjukkan klasifikasi skala prioritas pemeliharaan seperti terlihat pada Tabel III. Jumlah dan rentang selang ditentukan berdasarkan skor individu dan bobot parameter-parameter klasifikasi yang digunakan. Prioritas I menunjukkan bahwa transformator membutuhkan pemeliharaan segera. Sebaliknya Prioritas IV menunjukkan prioritas terakhir. Untuk memudahkan para teknisi, masing-masing skala prioritas diberikan warna dasar yang berbeda. Warna merah, kuning, hijau dan biru masing-masing menunjukkan skala prioritas I, II, III dan IV.

TABEL III. JUMLAH SKOR DAN KLASIFIKASI PRIORITAS PERAWATAN

\begin{tabular}{ccc}
\hline No & Jumlah Skor (TS) & Klasifikasi \\
\hline 1 & $0 \leq \mathrm{TS} \leq 28$ & Prioritas IV \\
\hline 2 & $28 \leq \mathrm{TS} \leq 54$ & Prioritas III \\
\hline 3 & $54 \leq \mathrm{TS} \leq 81$ & Prioritas II \\
\hline 4 & $81 \leq \mathrm{TS} \leq 100$ & Prioritas I \\
\hline
\end{tabular}

\section{Langkah Keempat}

Setelah diperoleh skala prioritas perawatan untuk masing-masing transformator, jadwal pemeliharaan dapat dibuat sesuai dengan hasil klasifikasi tersebut. Transformator dengan tingkat prioritas yang sama dapat diurutkan lebih lanjut untuk jadwal pemeliharaan sesuai total skor yang diperoleh. Jenis pemeliharaan yang dilakukan tergantung pada hasil pemantauan kondisi isolasi transformator-transformator tersebut.

\section{HASIL DAN PEMBAhasAN}

Pendekatan klasifikasi sederhana ini telah diterapkan dalam penentuan jadwal pemeliharaan untuk 29 buah transformator tegangan menengah, dengan tegangan operasi $20 \mathrm{kV} / 400 \mathrm{~V}$. Kapasitas transformator bervariasi dari 250kVA sampai dengan 2MVA. Produsen transformator juga bervariasi, dengan lebih dari 50\% diantaranya diproduksi di dalam negeri. Sebagian besar transformator telah bekerja selama lebih dari 15 tahun.

\section{A. Hasil Klasifikasi}

Hasil klasifikasi tingkat prioritas perawatan 29 transformator tersebut ditampilkan pada Tabel IV. Dari jumlah skor, dapat dilihat bahwa 2 transformator diklasifikasikan dalam Prioritas II, 1 transformator diklasifikasikan dalam Prioritas III dan sisanya sebanyak 26 buah transformator dikatagorikan dalam Prioritas IV. Prioritas perawatan tertinggi adalah untuk transformator dengan ID T10 dengan jumlah skor 67,6 dan diikuti oleh transformator dengan ID T28 dengan skor total 56,5. Prioritas III diberikan untuk pemeliharaan tranformator dengan ID T7 dengan jumlah skor 33,3. Tingkat prioritas perawatan tersebut didasarkan pada pengelompokan jumlah skor seperti tercantum pada Tabel III. Hasil analisis menunjukkan bahwa tidak ada transformator yang diklasifikasikan dalam Prioritas I. Di dalam makalah ini hanya tiga transformator tersebut yang akan dibahas lebih lanjut secara lebih terinci pada bagian selanjutnya.

TABEL IV. HASIL KLASIFIKASI

\begin{tabular}{lllcl}
\hline No & Lokasi & Kode & Jumlah Skor & $\begin{array}{c}\text { Hasil } \\
\text { Klasifikasi }\end{array}$ \\
\hline 1 & MPH-2 & T1 & 18,1 & Prioritas IV \\
\hline 2 & MPH-2 & T2 & 23,1 & Prioritas IV \\
\hline 3 & MPH-2 & T3 & 27,1 & Prioritas IV \\
\hline 4 & MPH-2 & T4 & 20,6 & Prioritas IV \\
\hline 5 & SS-H & T5 & 24,3 & Prioritas IV \\
\hline 6 & SS-C & T6 & 21,8 & Prioritas IV \\
\hline 7 & SS-C & T7 & 33,3 & Prioritas III \\
\hline 8 & SS-C & T8 & 21,8 & Prioritas IV \\
\hline 9 & SS-C & T9 & 21,8 & Prioritas IV \\
\hline 10 & SS-C & T10 & 67,6 & Prioritas II \\
\hline 11 & SS-G & T11 & 23,1 & Prioritas IV \\
\hline 12 & SS-G & T12 & 20,6 & Prioritas IV \\
\hline 13 & SS-G & T13 & 21,8 & Prioritas IV \\
\hline 14 & SS-A & T14 & 21,8 & Prioritas IV \\
\hline 15 & SS-A & T15 & 27,1 & Prioritas IV \\
\hline 16 & SS-A & T16 & 21,8 & Prioritas IV \\
\hline 17 & SS-F & T17 & 25,6 & Prioritas IV \\
\hline 18 & SS-F & T18 & 23,1 & Prioritas IV \\
\hline 19 & SS-B & T19 & 21,8 & Prioritas IV \\
\hline 20 & SS-B & T20 & 19,3 & Prioritas IV \\
\hline 21 & SS-D & T21 & 27,1 & Prioritas IV \\
\hline 22 & MPH-1 & T22 & 25,8 & Prioritas IV \\
\hline 23 & MPH-1 & T23 & 19,3 & Prioritas IV \\
\hline 24 & MPH-1 & T24 & 28,3 & Prioritas IV \\
\hline 25 & MPH-1 & T25 & 21,8 & Prioritas IV \\
\hline 26 & MPH-1 & T26 & 21,8 & Prioritas IV \\
\hline 27 & SS-E & T27 & 25,8 & Prioritas IV \\
\hline 28 & SS-E & T28 & 56,5 & Prioritas II \\
\hline 29 & R & T29 & 21,8 & Prioritas IV \\
\hline
\end{tabular}




\section{B. Interpretasi DGA}

Interpretasi DGA dengan menggunakan metode Key gas untuk transformator T10 mengindikasikan terjadinya arching di dalam minyak, sedangkan dengan metode Roger's ratio mengindikasikan terjadinya low energy discharge. Metode Duval's triangle mengindikasikan terjadinya gangguan termal dan elektrik. Dicatat juga bahwa interpretasi menggunakan metode TDCG menunjukkan bahwa transformator T10 berada dalam batas Condition I dan II.

Sebaliknya, hasil interpretasi TDCG untuk transformator T28 menunjukkan bahwa isolasi berada pada Condition III. Interpretasi menggunakan metode Key gas mengindikasikan terjadinya partial discharge. Sementara interpretasi menggunakan metode Duval's triangle mengindikasikan terjadinya low energy discharge. Dalam hal ini, interpretasi menggunakan metode Roger's ratio tidak memberikan kondisi yang spesifik.

Untuk transformator T7, interpretasi TDCG menunjukkan Condition I, sementara dengan metode Key gas mengindikasikan terjadinya kenaikan suhu tinggi pada isolasi selulose. Interpretasi dengan metode Duval's triangle mengindikasikan terjadinya low energy discharge. Interpretasi hasil uji DGA dari ketiga transformator tersebut (T10, T28 dan T7) ditampilkan pada Tabel V.

TABEL V. INTERPRETASI HASIL UJI DGA

\begin{tabular}{|c|c|c|c|}
\hline \multirow{2}{*}{ Parameter } & \multicolumn{3}{|c|}{ Kode Transformator } \\
\hline & T10 & T28 & T7 \\
\hline TDCG & Condition I & Condition III & Condition I \\
\hline Key gas & Arching in oil & $\begin{array}{l}\text { Partial } \\
\text { discharge }\end{array}$ & $\begin{array}{l}\text { Thermal } \\
\text { cellulose }\end{array}$ \\
\hline Roger's ratio & $\begin{array}{l}\text { Low energy } \\
\text { discharge }\end{array}$ & $N / A$ & $\begin{array}{l}\text { Low energy } \\
\text { discharge }\end{array}$ \\
\hline $\begin{array}{l}\text { Duval's } \\
\text { triangle }\end{array}$ & $\begin{array}{l}\text { Thermal and } \\
\text { electrical fault }\end{array}$ & $\begin{array}{l}\text { Low energy } \\
\text { discharge }\end{array}$ & $\begin{array}{l}\text { Low energy } \\
\text { discharge }\end{array}$ \\
\hline
\end{tabular}

\section{Perhitungan Skor Akhir}

Skor individu untuk masing-masing parameter dari ketiga transformator tersebut disajikan pada Tabel VI. Dapat dilihat bahwa hasil uji DGA memberikan skor yang tinggi untuk transformator T10 dan T28. Tes tegangan tembus minyak trafo juga memberikan kontribusi nilai yang tinggi. Hal ini menunjukkan bahwa isolasi kedua transformator tersebut tidak berada dalam kondisi yang baik. Sebaliknya, transformator T7 memperoleh skor individu yang lebih rendah untuk hasil uji DGA dan hasil tes tegangan tembus, dibandingkan dengan 2 transformator sebelumnya.

Jumlah skor akhir untuk transformator T10 dihitung dengan menggunakan Persamaan (1) seperti berikut:

$$
\begin{aligned}
T S= & {[(25 \times 10)+(100 \times 20)+(13 \times 20)+(100 \times 30)+(75 \times 10)+} \\
& (25 \times 5)+(75 \times 5)] /[10+20+20+30+10+5+5]=67.6
\end{aligned}
$$

Nilai untuk skor individu diambil dari Tabel VI, sedangkan bobot parameter diambil dari Tabel I. Dengan cara yang sama, hasil perhitungan jumlah skor akhir untuk transformator T28 dan T7 adalah 56,5 dan 33,3.
TABEL VI. JUMLAH SKOR TRANSFORMATOR T10, T28 DAN T7

\begin{tabular}{lccc}
\hline \multirow{2}{*}{ Parameter } & \multicolumn{3}{c}{ Kode Transformator } \\
\cline { 2 - 4 } & T10 & T28 & T7 \\
\hline TDCG & 25 & 75 & 25 \\
\hline Keygas & 100 & 100 & 40 \\
\hline Roger's ratio & 13 & 7 & 7 \\
\hline Duval's triangle & 100 & 38 & 38 \\
\hline Tegangan Tembus & 75 & 75 & 50 \\
\hline Pembebanan & 25 & 25 & 50 \\
\hline Temperatur & 75 & 75 & 50 \\
\hline
\end{tabular}

\section{Tindak Lanjut}

Sebagai tindak lanjut dari klasifikasi prioritas pemeliharaan seperti telah dijelaskan sebelumnya, maka dilakukan langkah pemeliharaan yang disesuaikan dengan hasil pemantauan kondisi transformator tersebut. Karena hasil uji tegangan tembus menunjukkan nilai yang relatif rendah, maka proses pemurnian minyak dilakukan untuk transformator T10 dan T28. Setelah proses pemurnian minyak, pemantauan secara berkesinambungan dilakukan pada kedua transformator tersebut, untuk memonitor kemungkinan peningkatan secara signifikan kandungan gas hidrokarbon yang terlarut dalam minyak.

\section{KESIMPULAN}

Pendekatan sederhana dalam penentuan prioritas pemeliharaan transformator tegangan menengah telah diaplikasikan pada 29 buah transformator, sehingga sangat berguna untuk membantu para teknisi dalam pemeliharaan peralatan. Pendekatan yang dibahas di sini dapat diperluas dengan menambahkan parameter lainnya untuk menunjang pengambilan keputusan dalam manajemen aset.

\section{REFERENSI}

[1] K. Giese, "Evaluation of electrical tests on transformerboard", IEEE EI Magazine, vol. 9, no. 2, pp. 22-25, March/April 1993.

[2] E. L. Brancato, "An update on multifactor ageing", IEEE EI Magazine, vol. 14, no. 5, pp.22-24, September/October 1998.

[3] A. Abu-Siada and S. Islam, "A new approach to identify power transformer criticality and asset management decision based on dissolved gas-in-oil analysis", IEEE Trans. on DEI, vol. 19, no. 3; pp. 1007-1012, June 2012.

[4] Y. Li, M. J. Tang, F. J. Wu, G. J. Zhang, S. H. Wang, Suwarno, "Aging assessment of power transformer using multi-parameters", Int. Journal on Elec. Eng. and Infor., vol. 5, no. 1, pp. 34-44, March 2013.

[5] M. Fischer and S. Tenbohlen, M. Schäfer and R. Haug, "Determining power transformers' sequence of service in power grids", IEEE Trans. on DEI, vol. 18, no. 5; pp. 1789-1797, October 2011.

[6] A. Akbari, A. Setayeshmehr, H. Borsi, and E. Gockenbach, I. Fofana, "Intelligent agent-based system using dissolved gas analysis to detect incipient faults in power transformers", IEEE EI Magazine, vol. 26, no. 6, pp. 27-40, November/December 2010.

[7] K. R. Hooft van Huysduynen, E. Gulski, J. J. Smit, L. Chmura, F. de Vries and A. Bun, "The development of asset management decision tools for HV SCFF cable circuits", Proc. of the 2010 Int. Conf. on Condition Monitoring and Diagnosis, Tokyo, pp. 603606, September, 2010.

[8] N. A. Muhamad, B. T. Phung, T. R. Blackburn, K. X Lai, "Comparative Study and Analysis of DGA Methods for Transformer Mineral Oil", Proc. of the 2007 IEEE Lausanne Powertech, Lausanne, pp. 45-50, July, 2007. 